\section{Growth Responses of Tomato Seedlings to Different Spectra of Supplemental Lighting}

\author{
Celina Gómez ${ }^{1,3}$ and Cary A. Mitchell ${ }^{2}$ \\ Department of Horticulture and Landscape Architecture, Purdue University, \\ 625 Agriculture Mall Drive, West Lafayette, IN 47907-2010
}

Additional index words. light-emitting diode, LED, high-pressure sodium, propagation, Solanum lycopersicum, solid-state lighting

\begin{abstract}
Seedlings of six tomato (Solanum lycopersicum) cultivars ('Maxifort', 'Komeett', 'Success', 'Felicity', 'Sheva Sheva', and 'Liberty') were grown monthly for 2-week treatment periods to determine photomorphogenic and developmental responses to different light-quality treatments from supplemental lighting (SL) across changing solar daily light integrals (DLIs). Seedlings were grown in a glass-glazed greenhouse at a midnorth latitude (lat. $40^{\circ} \mathrm{N}$, long. $86^{\circ} \mathrm{W}$ ) under one of five lighting treatments: natural solar light only (control), natural + SL from a 100-W high-pressure sodium (HPS) lamp, or natural $+\mathrm{SL}$ from arrays of red and blue light-emitting diodes (LEDs) using $80 \%$ red + $20 \%$ blue, $95 \%$ red $+5 \%$ blue, or $100 \%$ red. Varying solar DLI occurred naturally for all treatments, whereas constant DLI of $5.1 \mathrm{~mol} \cdot \mathrm{m}^{-2} \cdot \mathrm{d}^{-1}$ was provided for all SL treatments. Supplemental lighting increased hypocotyl diameter, epicotyl length, shoot dry weight, leaf number, and leaf expansion relative to the control, whereas hypocotyl elongation decreased when SL was applied. For all cultivars tested, the combination of red and blue in SL typically increased growth of tomato seedlings. These results indicate that blue light in SL has potential to increase overall seedling growth compared with blue-deficient LED SL treatments in overcast, variable-DLI climates.
\end{abstract}

Adequate growing conditions in greenhouses are crucial to ensure successful transplant production. A major limitation for tomato seedling propagation is that peak demand can occur when mean solar DLI is lowest. Low DLI, which typically is the result of a combination of short days and cloud cover, reduces the rate of seedling growth and thus extends the transplant production period. The recommended DLI for tomato seedling growth ranges from 13 to $16 \mathrm{~mol} \cdot \mathrm{m}^{-2} \cdot \mathrm{d}^{-1}$ (Fan et al., 2013; Moe et al., 2006). However, in a temperate, seasonally light-limited climate, sunlight rarely provides adequate DLI within greenhouses to produce high-quality seedlings when the propagation season begins (November, December, or April, depending on the cropping schedule). High-quality tomato seedlings should be uniform in size with well-developed leaves and roots; straight, short (12 to $13 \mathrm{~cm}$ in length),

Received for publication 12 Aug. 2014. Accepted for publication 13 Nov. 2014.

Research funded in part by the National Institute of Food and Agriculture, Specialty Crops Research Initiative grant 2010-51181-21369.

Statistical assistance from Judy Santini with the Purdue College of Agriculture Statistical Consulting Service and Wenyu Wang and Dr. Bruce Craig with the Purdue University Statistical Consulting Service is gratefully acknowledged. We thank Syndicate Sales for growth media and DeRuiter Seeds and Hazera Seeds for seed supply.

${ }^{1}$ Post-Doctoral Research Associate.

${ }^{2}$ Professor.

${ }^{3}$ To whom reprint requests should be addressed: e-mail cgomezva@purdue.edu. thick stems; and deep-green leaves (Jones, 2008; Lee et al., 2010). Nevertheless, quality requirements depend on the intended transplant use, because morphological preferences for scions, rootstocks, or non-grafted production seedlings are different (Chia and Kubota, 2010).

Supplemental lighting promotes growth of greenhouse-grown vegetable seedlings by increasing total DLI. High-pressure sodium lamps are the most widely used electric light source for greenhouse SL during transplant production. In general, HPS lamps provide an orange-biased spectrum by primarily emitting light in the range of 565 to $700 \mathrm{~nm}$. Nonetheless, it is widely accepted that any wavelength of light within the photosynthetically active radiation spectrum (400 to $700 \mathrm{~nm}$ ) contributes to photosynthesis and crop productivity (McCree, 1972). Thus, with their high-intensity capabilities, HPS lamps can deliver adequate supplemental DLI to support transplant production. However, over the past decade, interest has shifted toward alternative SL sources that can reduce production costs by decreasing electrical energy consumption while maintaining transplant quality. Because LED arrays typically have low power density $\left(\mathrm{kW} \cdot \mathrm{m}^{-2}\right)$ and offer a diversity of narrow wavebands, LED lamps can be designed to provide specific light spectra to potentially optimize seedling growth and morphology while using less energy than conventional HPS lighting fixtures.

Several studies have evaluated LEDs for sole-source lighting of vegetable transplants including tomato (Fan et al., 2013; Liu et al.,
2011; Nanya et al., 2012), pepper (Capsicum annuum) (Brown et al., 1995), cucumber (Cucumis sativus) (Hogewoning et al., 2010b; van Ieperen et al., 2012), eggplant (Solanum melongena) (Hirai et al., 2006), pea (Pisum sativum) (Wu et al., 2007), spinach (Spinacea oleracea) (Yorio et al., 2001), radish (Raphanus sativus) (Yorio et al., 2001), and lettuce (Latuca sativa) (Hoenecke et al., 1992; Kim et al., 2005; Massa et al., 2008). Findings from sole-source LED lighting research indicate that red light ( 600 to $700 \mathrm{~nm}$ ) generally promotes fresh and dry weight gain, stem elongation, and leaf expansion (Heo et al., 2012; Johkan et al., 2010; Wu et al., 2007), whereas blue light (400 to $500 \mathrm{~nm}$ ) affects morphological development and biomass production in species-specific and growthenvironment-specific ways (Johkan et al., 2010; Kigel and Cosgrove, 1991; Savvides et al., 2012; Wang et al., 2009). Most studies using LEDs for sole-source lighting demonstrate the need to supplement monochromatic red LEDs with blue light to obtain acceptable growth and development (Cope and Bugbee, 2013; Goins et al., 1998; Hoenecke et al., 1992; Tripathy and Brown, 1995; Yorio et al., 1998). However, if LEDs are used to supplement sunlight, additional blue light may not be necessary because the broad solar spectrum contains significant amounts of blue light at midday, which may be sufficient for normal plant growth and development.

Other studies have evaluated LEDs as SL for greenhouse vegetable propagation (Gislerød et al., 2012; Hernández and Kubota, 2012, 2014a, 2014b; Hogewoning et al., 2012). Although general crop responses have not been broadly determined, one conclusion from those studies is that growth and morphological responses to LED SL are species-specific, yet potential cultivar-specific responses to light quality remain to be defined. The objective of the present study was to quantify growth responses of six tomato cultivars to different light-quality treatments from SL. We compared photomorphogenic and developmental responses to SL across changing solar DLIs at a midnorth latitude to reveal cultivar and/or spectral effects. Results are expected to provide baseline information to assist in designing SL protocols for propagating tomato seedlings intended for grafting or for direct transplanting into greenhouses or field production.

\section{Materials and Methods}

Plant material and growing conditions. Cultivars with different functional roles (i.e., rootstock or production seedlings intended for grafting or grow-out on own roots) and differing fruit size/shape were selected. Seeds of rootstock 'Maxifort' (S. lycopersicum $\times S$. habrochaites; De Ruiter Seeds, Bergshenhoek, The Netherlands) and production cultivars Komeett (De Ruiter Seeds; truss type), Success (De Ruiter Seeds; truss type), Felicity (Hazera Seeds, Haifa, Israel; cherry type), Sheva Sheva (Hazera Seeds; Roma type), and Liberty (Hazera Seeds; beefsteak type) were grown for 3 weeks from germination in 
a glass-glazed greenhouse in West Lafayette, IN (lat. $40^{\circ} \mathrm{N}$, long. $86^{\circ} \mathrm{W}$ ). Seeds were sown into 17-cell seedling trays of Agrifoam soilless plugs $(5 \times 2.5 \mathrm{~cm}$; SteadyGROWpro; Syndicate Sales, Kokomo, IN) during the first week of each month in 2012. Once cotyledons had expanded fully ( $\approx 7 \mathrm{~d}$ from sowing), eight seedlings of each cultivar were selected for uniformity and placed randomly in each of five lighting treatments. Within each treatment, seedlings were randomly rotated daily to minimize location effects within the experimental area. Seedlings were irrigated as necessary with acidified water supplemented with a combination of two water-soluble fertilizers (3:1 mixture of $15 \mathrm{~N}-2.2 \mathrm{P}-12.5 \mathrm{~K}$ and $21 \mathrm{~N}-2.2 \mathrm{P}-16.6 \mathrm{~K}$, respectively; The Scotts Co., Marysville, $\mathrm{OH}$ ) to provide the following (in $\mathrm{mg} \cdot \mathrm{L}^{-1}$ ): 200 $\mathrm{N}-\mathrm{NO}_{3}, 26$ phosphorus, 163 potassium, 50 calcium, 20 magnesium, and micronutrients. Average ambient day (from 0500 to $2100 \mathrm{HR}$ ) and night (from 2100 to $0500 \mathrm{HR}$ ) air temperature of the greenhouse were set at 27 and $15^{\circ} \mathrm{C}$, respectively. Air temperature and solar DLI were monitored using fine wire thermocouples (Type K, 0.1-mm diameter) and a quantum sensor (190 SB; LI-COR Biosciences, Lincoln, NE), respectively, interfaced to a data logger (CR1000; Campbell Scientific, Logan, UT). Three thermocouples were used (one for each light source) and placed directly under a leaf (near-canopy air temperature) at the center of a given treatment. DLI data were collected at midplant height in the center of a treatment without SL. Measurements were made every $10 \mathrm{~s}$ and data were recorded at 10-min intervals.

Lighting treatments. Five lighting treatments were evaluated in the greenhouse: natural solar light only (control); natural + SL from a 100-W HPS lamp (Ceramalux; Philips Lighting Company, Somerset, NJ) emitting $13 \%, 49 \%$, and $38 \%$ broadband blue, green (500 to $600 \mathrm{~nm}$ ), and red light, respectively; or natural + SL from LEDs using $80 \%$ red $+20 \%$ blue (80R-20B), 95\% red $+5 \%$ blue $(95 \mathrm{R}-5 \mathrm{~B})$, or $100 \%$ red (100R-0B). The red and blue LEDs used in the arrays had 627-nm and 450-nm peak wavelengths, respectively (as specified by the manufacturer). The spectral distribution of sunlight (at solar noon), for HPS lamps, and for the LED arrays are shown in Figure 1. All SL treatments provided an average DLI of $5.1 \mathrm{~mol} \cdot \mathrm{m}^{-2} \cdot \mathrm{d}^{-1}(23-\mathrm{h}$ photoperiod from 0000 to $\left.2300 \mathrm{HR} ; 61 \pm 2 \mu \mathrm{mol} \cdot \mathrm{m}^{-2} \cdot \mathrm{s}^{-1}\right)$ at midplant height [measured with a spectroradiometer (EPP-2000; StellarNet Inc., Tampa, FL)]. Light pollution from one treatment to another along the bench was minimized by allowing sufficient separation distance between treatments, delimited by $2 \mu \mathrm{mol} \cdot \mathrm{m}^{-2} \cdot \mathrm{s}^{-1}$ or less from adjacent arrays. Scans of direct sunlight were recorded monthly at solar noon inside the greenhouse (not under SL) with a spectroradiometer. These measurements were collected on clear-sky and overcast days to calculate the average percentage of solar blue, green, and red light representative of each month.

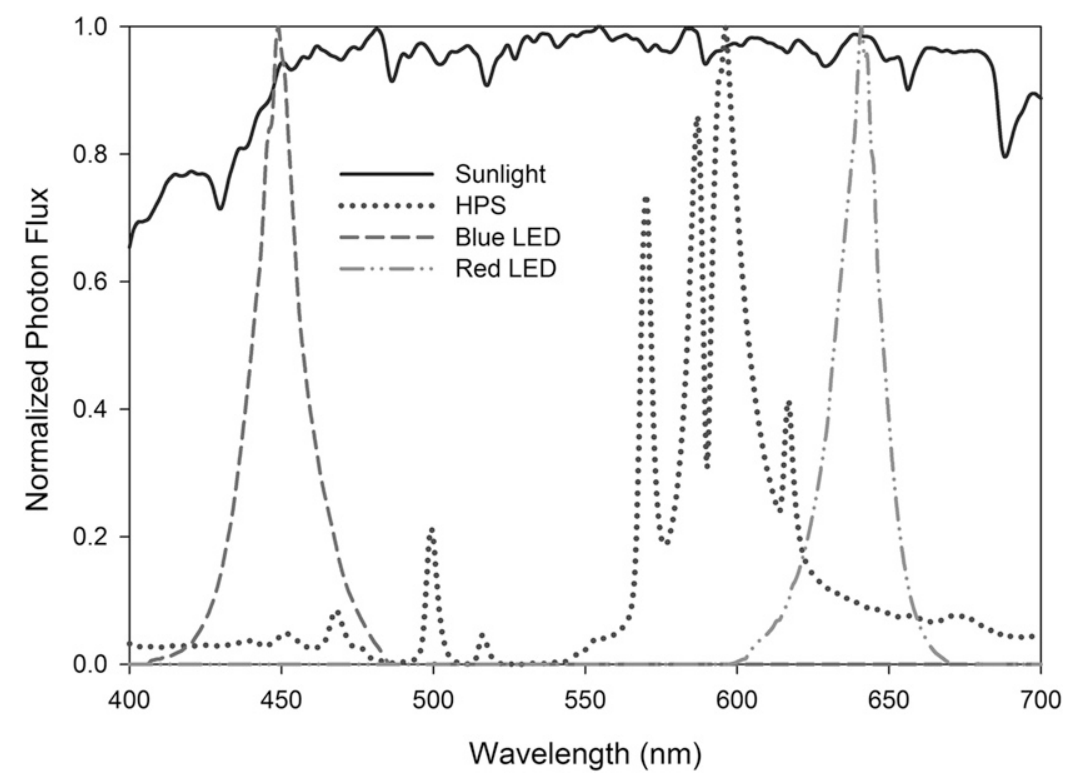

Fig. 1. Spectral distribution of sunlight (at solar noon), high-pressure sodium (HPS) lamps, or arrays with blue and red-light-emitting diodes (LEDs).

Light-emitting diode source. Overhead LED arrays (Orbital Technologies Corporation, Madison, WI) were designed specifically for greenhouse transplant propagation. Each $1.2 \mathrm{~m} \times 1.3-\mathrm{m}$ array consisted of eight aluminum bars with alternating red and blue LEDs. Each red and blue bar had 28 or 24 LEDs, respectively, along their 1.2-m length. Arrays were air-cooled through hollow aluminum mounts and fans that drew greenhouse air into the center of each bar and exhausted waste heat from both ends. The 1.2 -cm-wide bars were spaced $16 \mathrm{~cm}$ apart and oriented east to west. The sunlightshading factor from the LED arrays and the HPS lamps was less than $10 \%$ at the bench surface.

Plant measurements. Growth parameters were measured $14 \mathrm{~d}$ after SL treatment initiation. Hypocotyl diameter was measured immediately below the cotyledons using an electronic digital caliper (DigiMax; Wiha, Schonach, Germany). Hypocotyl length and epicotyl length were measured using a ruler. Seedling shoots were then cut at the plug surface and leaf number (for leaves greater than $1 \mathrm{~cm}$ in length) and total leaf area were recorded. Leaf area was measured using a leaf area meter (LI-3000A; LI-COR Biosciences). Shoot dry weight was measured after drying samples in a forced-air oven at $77{ }^{\circ} \mathrm{C}$ for $72 \mathrm{~h}$.

Data analysis. The relationship between each response variable and the monthly average solar DLI (DLI $\mathrm{ave}_{\text {e }}$ ) was modeled with the GLIMMIX procedure of SAS (Version 9.2; SAS Institute, Cary, NC) using a generalized linear mixed model with a Gaussian distribution and an identity link function. Analysis of the data were conducted using $\mathrm{DLI}_{\mathrm{ave}}$, treatment, cultivar, $\mathrm{DLI}_{\mathrm{ave}} \times$ cultivar, and treatment $\times$ cultivar as fixed factors and $\mathrm{DLI}_{\mathrm{ave}} \times$ treatment and $\mathrm{DLI}_{\text {ave }} \times$ treatment $\times$ cultivar as random factors to account for the split-plot structure of our experimental design (treatment was the whole plot factor and cultivar was the subplot factor). The treatment and cultivar main effect estimates describe the intercepts associated with the regression lines. The interaction effect estimates describe differences in slopes. All pairwise comparisons were completed using Tukey's honestly significant difference test with a significance level of $\alpha=0.05$. The appropriateness of these models was checked by examining the normality and constant variance of the residuals. Data collected in February and May were excluded from this analysis because of lack of replication for some cultivars. The data from June were also not included in the analysis. An explanation for June's exclusion can be found in the "Results and Discussion" section.

\section{Results and Discussion}

Environmental conditions. Solar DLI and near-canopy air temperature measured inside the greenhouse during the experimental period are shown in Figure 2. DLI ave in June was more than double the $\mathrm{DLI}_{\mathrm{ave}}$ measured in July (month within the analysis with the second highest $\mathrm{DLI}_{\mathrm{ave}} ; 29.3$ vs. $13.3 \mathrm{~mol} \cdot \mathrm{m}^{-2} \cdot \mathrm{d}^{-1}$, respectively) (Fig. 2A). Thus, data in June were excluded from the statistical model because we chose not to draw inference in the large range of $\mathrm{DLI}_{\mathrm{ave}}$ between June and July. Nonetheless, the general growth responses recorded in June indicate that somewhere between the range of $\mathrm{DLI}_{\text {ave }}$ from June and July, seedling growth was DLI saturated (data not shown). From the data used in the analysis, the average contribution of SL to total DLI ranged from $28 \%$ in July to $79 \%$ in December. Similarly, the highest and lowest 24-h average near-canopy air temperatures were recorded in July (26.5 ${ }^{\circ} \mathrm{C}$ ) and December $\left(21.4{ }^{\circ} \mathrm{C}\right)$, respectively (Fig. 2B). The lack of differences among 
near-canopy air temperatures recorded under our three light sources (sunlight, HPS, and LEDs) suggests that temperature effects from SL were most likely negligible. However, the large month-to-month variability in air temperature (falling outside of set points) implies that any changes in plant growth measured during the different months were partly the result of the effect of sunlight's short-wave radiation on greenhouse air temperature. Figure 3 shows the average percentage of midday solar blue, green, and red light representative of each month and indicates that the relative percentages of broadband light quality from sunlight were relatively uniform across months ranging from $25 \%$ to $33 \%$ blue, $35 \%$ to $38 \%$ green, and $30 \%$ to $39 \%$ red light. Interestingly, although light intensity was lower in overcast compared with clear-sky days, the relative percentages of broadband light quality at midday were nearly constant within months (data not shown).

Light quality effects on plant growth and morphology. We found a linear relationship between seedling growth and $\mathrm{DLI}_{\text {ave }}$ for all treatments measured in our study (Fig. 4). Test of fixed effects in statistical models indicated significant treatment differences (Table 1). Based on the mean associated with a regression line at the midpoint $\mathrm{DLI}_{\mathrm{ave}}$, we found that except for hypocotyl length, all SL treatments increased growth and development in tomato seedlings compared with control (Table 2). Seedlings grown under HPS, 95R-5B, or $80 \mathrm{R}-20 \mathrm{~B}$ had similar growth but resulted in $18 \%$ thicker hypocotyls, up to $55 \%$ larger leaves, and up to $50 \%$ more shoot dry weight than to those grown under 100R-0B SL. Leaf number per seedling was instead greatest for those grown under 95R-5B (4.7 leaves) but was not different among HPS, 100R-0B, or 80R-20B SL.

To date, limited research has evaluated LEDs as SL sources for vegetable transplant production. Studies conducted in desert climates (i.e., Tucson, AZ) have shown that SL with red light only is sufficient to increase tomato or cucumber seedling growth (shoot dry weight, leaf count, or leaf area) relative to seedlings grown without SL (Hernández and Kubota, 2012, 2014a, 2014b). Our study indicated that, in general, 100R-0B was the least beneficial of the SL treatments for increasing seedling growth relative to unsupplemented controls (Table 2). The underlying cause of differences between our findings and those of Hernández and Kubota (2012, $2014 a, 2014 b$ ) may be associated with differences in solar DLI during the experimental periods. Cope and Bugbee (2013) suggested that constant-high photosynthetic photon fluxes $(P P F \mathrm{~s})$ can partially substitute for low percentages of blue in the light spectrum. Therefore, different red:blue photon flux ratios from SL may not strongly affect vegetable seedling growth in non-cloudy, high-insolation-rate environments that allow for relatively constant DLI backgrounds. However, in the present study, solar DLI fluctuated by up to $13.1 \mathrm{~mol} \cdot \mathrm{m}^{-2} \cdot \mathrm{d}^{-1}$ within an experimental

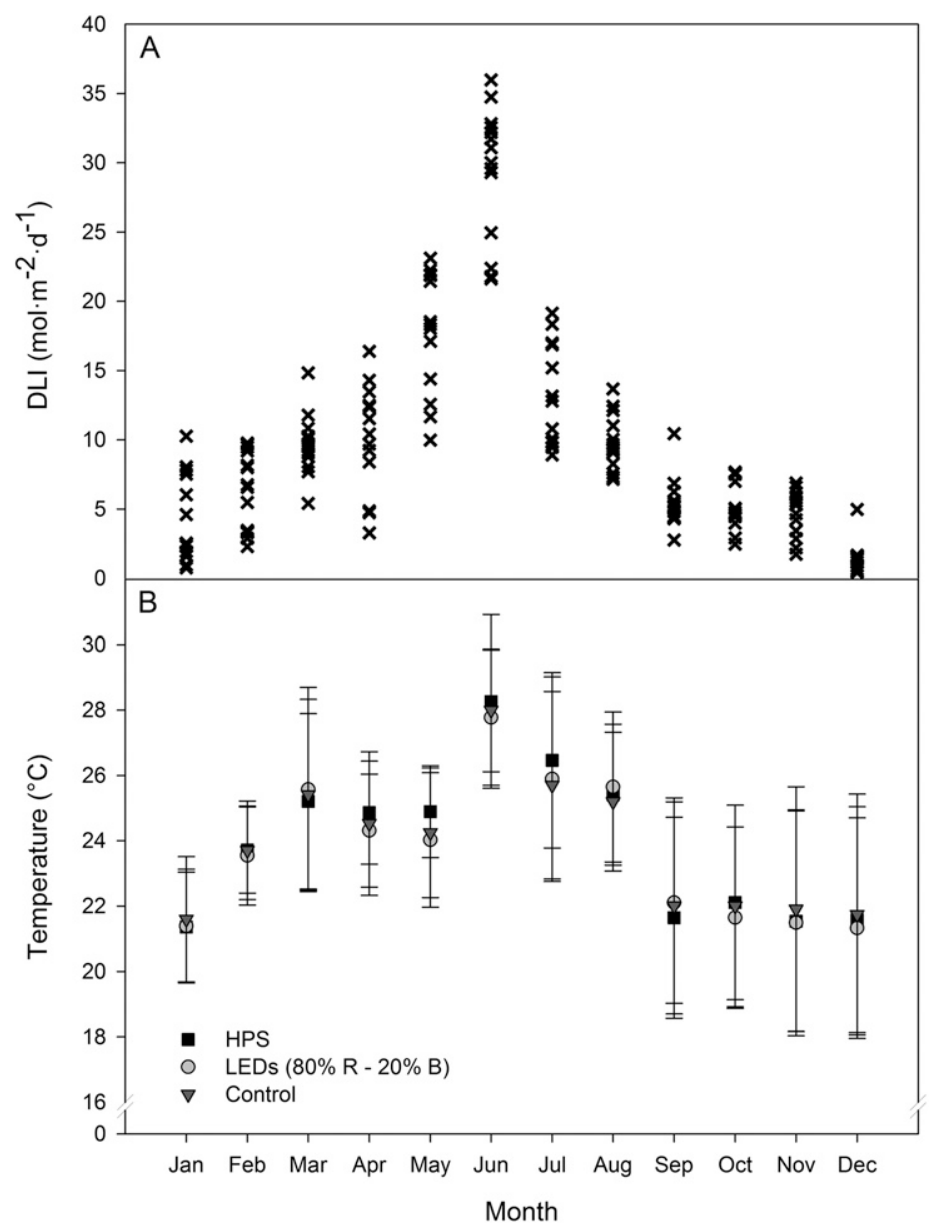

Fig. 2. Daily light integral (DLI) (A) and near-canopy air temperature ( \pm SD) (B) measured inside a glass-glazed greenhouse in West Lafayette, IN, during the experimental dates in 2012. DLI data were collected at midplant height under no supplemental lighting. Temperature data represent the average 24-h near-canopy air temperature measured under each light source: HPS = high-pressure sodium lamps; LEDs = arrays of light-emitting diodes $(\mathrm{R}=$ red light; $\mathrm{B}=$ blue light $)$; control = sunlight.

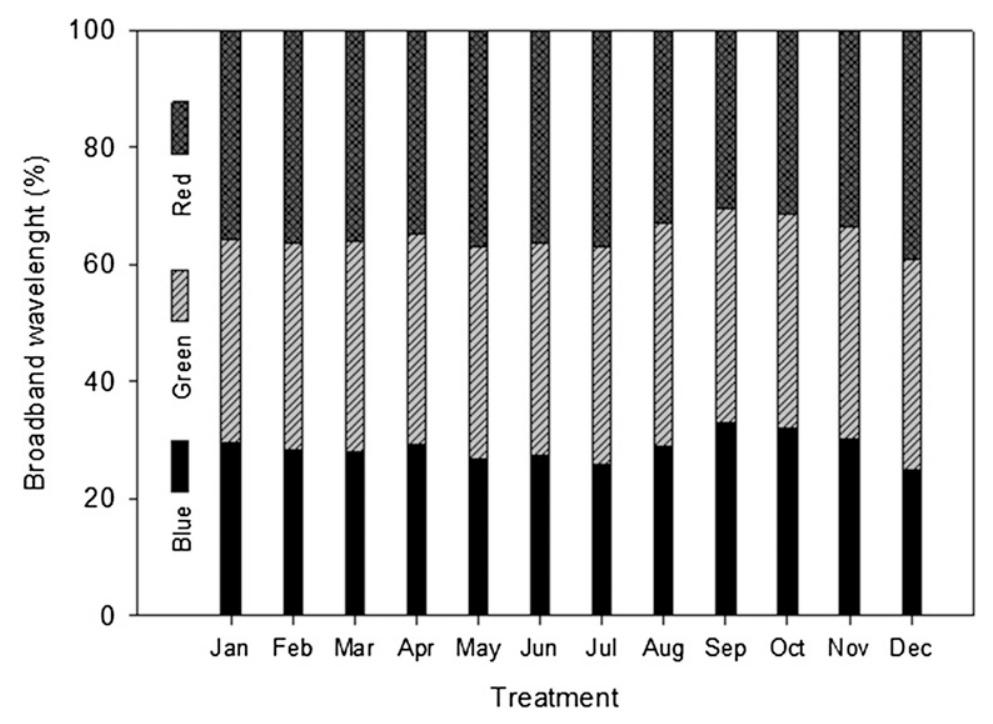

Fig. 3. Percentage of broadband blue ( 400 to $500 \mathrm{~nm}$ ), green ( 500 to $600 \mathrm{~nm}$ ), and red (600 to $700 \mathrm{~nm}$ ) light calculated from the photosynthetic photon flux $(P P F)$ measured at solar noon inside a glass-glazed greenhouse in West Lafayette, IN, in 2012. Spectral scans were collected during the experimental period at bench height. Data represent an average of at least two scans per month on clear-sky and overcast days. 
period (Fig. 2). With high day-to-day fluctuations of solar DLI (leading to both highand low-DLI environments), plant responses to spectral differences from SL were observed.
Our findings support studies showing enhanced morphological development of vegetable seedlings grown under sole-source lighting using a combination of red and blue light compared with monochromatic red light

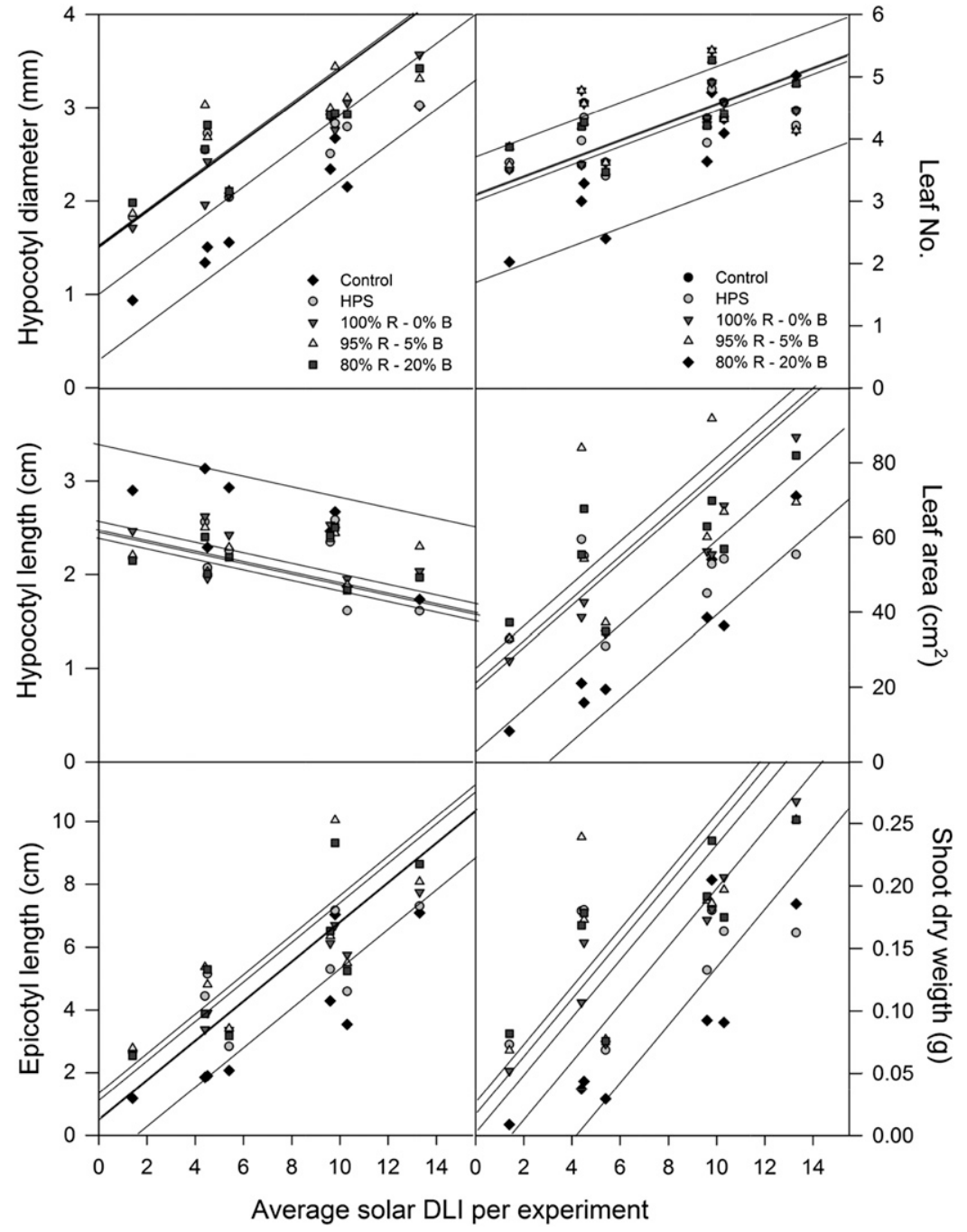

Fig. 4. Effect daily light integral (DLI) on several growth parameters measured for tomato seedlings propagated in a glass-glazed greenhouse in West Lafayette, IN, under different lighting treatments. The treatments evaluated were natural solar light only (control); natural + supplemental light [SL; 5.1 $\mathrm{mol} \cdot \mathrm{m}^{-2} \cdot \mathrm{d}^{-1}$ (23-h photoperiod from 0000 to $\left.\left.2300 \mathrm{HR} ; 61 \pm 2 \mu \mathrm{mol} \cdot \mathrm{m}^{-2} \cdot \mathrm{s}^{-1}\right)\right]$ from a high-pressure sodium (HPS) lamp, or natural + SL from light-emitting diodes using different red (R) and blue (B) percentages. Each data point represents the average of 48 seedlings with all measurements taken $14 \mathrm{~d}$ after treatment initiation. alone (Brown et al., 1995; Hogewoning et al., 2010b; Kim et al., 2005; Nanya et al., 2012; van Ieperen et al., 2012). A possible explanation for the similarities between our results and those of others using LEDs as sole-source lighting may be associated with the $23-\mathrm{h}$ photoperiod used in the present study. When SL was extended past the natural photoperiod from sunlight, it was perceived by seedlings as sole-source lighting. Therefore, the growth responses measured in our study are most likely the result of an interaction between supplemental and sole-source light-quality plant responses.

It has been shown that during early vegetative growth, tomato seedlings respond positively to increases in total DLI by either increasing the $P P F$ at leaf level (Bleasdale, 1973; Bruggink, 1987; McAvoy and Janes, 1990 ) or by extending the photoperiod (up to 24 h of light) (Calvert, 1959; Demers et al., 1998; Omura et al., 2001; Sysoeva et al., 2012). Because the average intensity of SL was a limiting factor in our study, we used a 23-h photoperiod to maximize the DLI delivered from SL aiming to approach a target total DLI of $16 \mathrm{~mol} \cdot \mathrm{m}^{-2} \cdot \mathrm{d}^{-1}$. Although physiological injuries (chlorosis or necrosis) caused by long photoperiods ( $16 \mathrm{~h}$ or longer) have been reported for vegetative, mature, and reproductive tomato plants (Arthur, 1936; Cushman and Tibbitts, 1998; Demers et al., 1998; Dorais et al., 1996; Globig et al., 1997; Withrow and Withrow, 1949), fewer studies have shown such effects on juvenile tomato seedlings (Hillman, 1956). Moreover, it has been proposed that when long photoperiods have no negative effect on plant growth, then prolonged lighting at lower intensities is a better approach to supplement sunlight than are higher light intensities of shorter duration (Hurd and Thornley, 1974; Moe, 1997). Furthermore, diurnal temperature fluctuations $8{ }^{\circ} \mathrm{C}$ or greater between day and night air temperatures prevent chlorosis in species otherwise adversely affected by long photoperiods per se (Cao and Tibbitts, 1992; Demers and Gosselin, 2002; Hillman, 1956; Matsuda et al., 2012, 2014; Murage and Masuda, 1997; Ohyama et al., 2005a, 2005b; Omura et al., 2001; Tibbitts et al., 1990). In our study, damage to early vegetative growth was further prevented (no visual damage was observed) by combining a long

Table 1. Significance level for the test of fixed effects in linear mixed models evaluating several growth parameters measured for tomato seedlings propagated in a glass-glazed greenhouse in West Lafayette, IN, under different lighting treatments. ${ }^{z, y}$

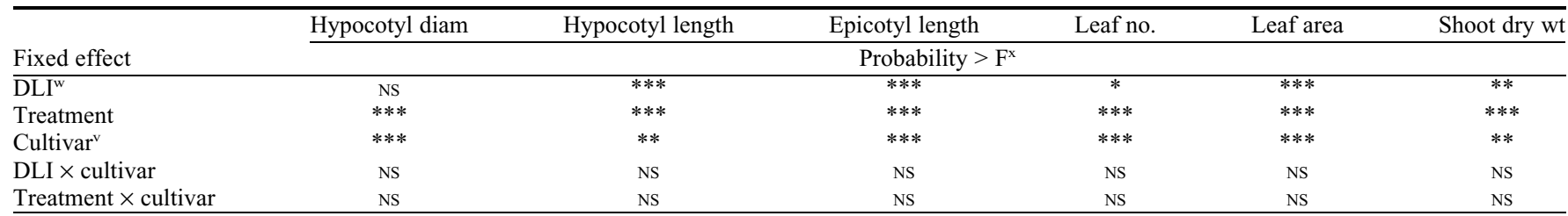

${ }^{2}$ The treatments evaluated were natural solar light only (control); natural + supplemental lighting (SL) from a high-pressure sodium lamp; or natural + SL from light-emitting diodes using either $80 \%$ red $+20 \%$ blue, $95 \%$ red $+5 \%$ blue, or $100 \%$ red light.

${ }^{y}$ The experiment was conducted every month in 2012. Data from February, May, and June were not included in the model.

${ }^{x} P$ values from $F$ tests.

${ }^{\mathrm{w}} \mathrm{DLI}=$ daily light integral.

${ }^{v}$ The cultivars evaluated were Maxifort, Komeett, Success, Felicity, Sheva Sheva, and Liberty.

***, **, $*$, Ns indicate statistical significance at the $0.001,0.01$, and $0.05 P \leq$ level and nonsignificant, respectively. 
Table 2. Least squares means for several growth parameters measured for tomato seedlings propagated in a glass-glazed greenhouse in West Lafayette, IN, under different lighting treatments. ${ }^{\mathrm{z}, \mathrm{y}, \mathrm{x}}$

\begin{tabular}{|c|c|c|c|c|c|c|}
\hline$\overline{\text { Treatment }}$ & Hypocotyl diam (mm) & Hypocotyl length $(\mathrm{cm})$ & Epicotyl length $(\mathrm{cm})$ & Leaf no. & Leaf area $\left(\mathrm{cm}^{2}\right)$ & $\overline{\text { Shoot dry wt (g) }}$ \\
\hline Control & $1.6 \mathrm{c}^{\mathrm{w}}$ & $3.0 \mathrm{a}$ & $3.1 \mathrm{~b}$ & $2.7 \mathrm{c}$ & $21.4 \mathrm{c}$ & $0.06 \mathrm{c}$ \\
\hline HPS & $2.8 \mathrm{a}$ & $2.1 \mathrm{bc}$ & $5.4 \mathrm{a}$ & $4.3 \mathrm{~b}$ & $59.4 \mathrm{a}$ & $0.18 \mathrm{a}$ \\
\hline $100 \% \mathrm{R}-0 \% \mathrm{~B}$ & $2.3 \mathrm{~b}$ & $2.3 \mathrm{~b}$ & $4.9 \mathrm{a}$ & $4.2 \mathrm{~b}$ & $41.0 \mathrm{~b}$ & $0.12 \mathrm{~b}$ \\
\hline $95 \% \mathrm{R}-5 \% \mathrm{~B}$ & $2.8 \mathrm{a}$ & $2.1 \mathrm{bc}$ & $5.6 \mathrm{a}$ & $4.7 \mathrm{a}$ & $63.4 \mathrm{a}$ & $0.17 \mathrm{a}$ \\
\hline $80 \% \mathrm{R}-20 \% \mathrm{~B}$ & $2.8 \mathrm{a}$ & $2.0 \mathrm{c}$ & $5.0 \mathrm{a}$ & $4.3 \mathrm{~b}$ & $58.1 \mathrm{a}$ & $0.16 \mathrm{a}$ \\
\hline
\end{tabular}

${ }^{\mathrm{z}}$ The treatments evaluated were natural solar light only (control); natural + supplemental light [SL; $5.1 \mathrm{~mol} \cdot \mathrm{m}^{-2} \cdot \mathrm{d}^{-1}(23-\mathrm{h}$ photoperiod from 0000 to $2300 \mathrm{HR} ; 61 \pm 2$ $\left.\left.\mu \mathrm{mol} \cdot \mathrm{m}^{-2} \cdot \mathrm{s}^{-1}\right)\right]$ from a high-pressure sodium (HPS) lamp, or natural + SL from light-emitting diodes using different red (R) and blue (B) percentages.

${ }^{\mathrm{y}}$ The experiment was conducted every month in 2012. Data from February, May, and June were not included in the statistical model.

${ }^{x}$ Data represent a pooled average for cultivars Maxifort, Komeett, Success, Felicity, Sheva Sheva, and Liberty.

${ }^{w}$ Means within columns followed by the same letter are not different based Tukey's honestly significant difference test at $P \leq 0.05$.

SL photoperiod (used to maximize DLI) with a 16/8-h day/night thermoperiod of pronounced temperature differential (greater than $\left.10{ }^{\circ} \mathrm{C}\right)$.

Hypocotyls of seedlings grown without SL elongated up to $1 \mathrm{~cm}$ more than those grown under SL (Table 2). Furthermore, the 100R-0B SL treatment produced the second longest hypocotyls $(2.3 \mathrm{~cm})$. In contrast, epicotyl length was unaffected by SL treatment, but epicotyls of seedlings grown without SL were at least $1.8 \mathrm{~cm}$ shorter than those of seedlings grown under SL. Hypocotyl elongation of tomato seedlings is known to respond to photomorphogenic cues (Ballaré et al., 1995; Blom et al., 1995; Kasperbauer and Peaslee, 1973; Volmaro et al., 1998) and reflects the subterranean growth of seedlings in nature before they break crust during the germination process, whereas epicotyls, which support active photosynthetic leaves, are affected by both photomorphogenic and photosynthetic cues. Thus, the general decrease in hypocotyl elongation and increase in epicotyl length in response to SL could be attributed to the perception of antagonistic signals received by different photoreceptors present in hypocotyl and epicotyl tissues.

Some variability in hypocotyl length between seedlings grown under SL treatments and those without SL could have been the result of different end-of-day (EOD) light quality sensed by phytochrome photoreceptors, which are known to affect hypocotyl elongation (Blom et al., 1995; Kasperbauer and Peaslee, 1973). Seedlings grown under SL received a significant percentage of EOD red light caused by LED or HPS emission spectra at and beyond sunset (Fig. 1). Although SL-grown plants experienced natural daylength, it was overlaid with low-level supplemental DLI and, thus, SL reduced the natural EOD far-red light effect from sunlight. In contrast, controls received only sunlight and, consequently, far-red-enriched EOD light. A high red: far-red EOD spectrum is known to produce short, compact transplants (Chia and Kubota, 2010; Decoteau and Friend, 1991; Lund et al., 2007) and, thus, may explain the general trend for the shorter hypocotyls of SL-grown seedlings.

Our study also showed that 80R-20B SL produced more compact hypocotyls compared with those of seedlings grown under
100R-0B (2.0 vs. $2.3 \mathrm{~cm}$, respectively) (Table 2). Several growth chamber studies using sole-source LED lighting have reported blue light-mediated inhibition of hypocotyl elongation for tomato (Nanya et al., 2012), pepper, (Brown et al., 1995), cucumber (Shinkle and Jones, 1988), sunflower (Helianthus annuus) (Cosgrove and Green, 1981), pea (Kigel and Cosgrove, 1991), and lettuce (Dougher and Bugbee, 2001; Hoenecke et al., 1992), which likely are mediated by the blue-light photoreceptors cryptochrome and/or phototropin (Ballaré et al., 1995; Volmaro et al., 1998). In contrast, it has been noted that $100 \%$ red or $100 \%$ blue SL in the greenhouse caused similar hypocotyl elongation of tomato seedlings, but $100 \%$ blue SL caused taller, thinner hypocotyls for cucumber seedlings compared with $100 \%$ red (R. Hernández and C. Kubota, unpublished data). Our findings suggest that increasing proportions of blue in SL can reduce hypocotyl elongation in tomato. Longer hypocotyls typically are desired for rootstock cultivars because they allow for ease of grafting and decrease the risk of scion exposure to soil/substrate surfaces. However, hypocotyl elongation is not a desired characteristic for non-grafted production seedlings, because it may lead to weak transplants (Jones, 2008).

Although not statistically significant, for five of the six growth parameters measured in our study, 95R-5B tended to promote more growth than did 80R-20B SL (Fig. 4; Table 2 ). This indicates that there likely is a threshold above which blue light increases tomato seedling development before it starts acting antagonistically toward growth. Numerous studies have shown that increasing blue light can reduce stem length and leaf area and increase leaf mass area for different crop species (Cope and Bugbee, 2013; Hogewoning et al., 2010a, 2010b; Li and Kubota, 2009; Trouwborst et al., 2010). However, the extent to which blue light affects plant growth and development is not yet fully understood. Research by Cope and Bugbee (2013) and Dougher and Bugbee (2001) has sought to determine whether certain growth parameters are better predicted by either absolute $\left(\mu \mathrm{mol} \cdot \mathrm{m}^{-2} \cdot \mathrm{s}^{-1}\right.$ of blue photons) or relative (percentage of total $P P F$ ) blue light. From their findings, it is apparent that blue light responses are species-dependent and that growth inhibition by blue light could depend on the total intensity of light and/or the relative distribution of light quality. Further research evaluating different red:blue photon flux ratios to identify specific thresholds to optimize growth for different cultivars and species of greenhouse-grown vegetable seedlings would be of interest.

Cultivar main effects. Of particular interest to growers are the species- and cultivar-specific responses to LED SL. Studies have shown that some plant responses to greenhouse SL are species- and cultivar-specific (Gunnlaugsson and Adalsteinsson, 2006; Hernández and Kubota, 2014a; Hogewoning et al., 2012), yet the lack of a treatment $\times$ cultivar interaction found in our study suggests that although genetic variation was apparent among cultivars, their response to a given SL treatment was similar (Table 1).

All cultivars showed a linear relationship between seedling growth and $\mathrm{DLI}_{\text {ave }}$ (data not shown). Based on the mean associated with a regression line at the midpoint $\mathrm{DLI}_{\mathrm{ave}}$, we found that hypocotyl diameter for 'Komeett' and 'Success' was $12 \%$ thicker than for 'Felicity' and 'Sheva Sheva' but similar to 'Liberty' and 'Maxifort' (Table 3). 'Komeett' produced the longest hypocotyls, whereas hypocotyl length for 'Felicity' was $0.4 \mathrm{~cm}$ shorter than that for 'Liberty' or 'Sheva Sheva'. Epicotyls of 'Success' and 'Felicity' were 15\% and 20\% shorter than those of 'Maxifort', respectively. 'Maxifort' also produced more and larger leaves than any other cultivar, and its shoot dry weight was $25 \%$ higher than that of 'Felicity'. However, occurrence of intumescence was observed in 'Maxifort' leaves throughout the experiment, most likely as a result of a lack of ultraviolet-B radiation in the greenhouse (Craver et al., 2014).

The greater growth (epicotyl length, leaf count, leaf area, and shoot dry weight) measured for 'Maxifort' relative to the other production cultivars can be attributed to its vigorous growth pattern (De Ruiter Seeds, unpublished data). Nonetheless, because 'Maxifort' is a rootstock cultivar strictly used for grafting, leaf growth responses are considered less important than those for stem morphology, especially hypocotyl length and diameter. In contrast, leaf growth and development are critical growth responses for production cultivars, because they set precedence for the development of active photosynthetic leaves. We found that all production cultivars had similar leaf area. 
Table 3. Least squares means for several growth parameters measured on different cultivars of tomato seedlings propagated in a glass-glazed greenhouse in West Lafayette, IN. z,y

\begin{tabular}{|c|c|c|c|c|c|c|}
\hline$\overline{\text { Cultivar }}$ & Hypocotyl diam (mm) & Hypocotyl length $(\mathrm{cm})$ & Epicotyl length $(\mathrm{cm})$ & Leaf no. & Leaf area $\left(\mathrm{cm}^{2}\right)$ & Shoot dry wt (g) \\
\hline Maxifort & $2.5 \mathrm{ab}^{\mathrm{x}}$ & $2.2 \mathrm{bc}$ & $5.4 \mathrm{a}$ & $4.7 \mathrm{a}$ & $62.5 \mathrm{a}$ & $0.15 \mathrm{a}$ \\
\hline Felicity & $2.3 \mathrm{~b}$ & $2.0 \mathrm{c}$ & $4.6 \mathrm{~b}$ & $4.1 \mathrm{~b}$ & $43.1 \mathrm{~b}$ & $0.12 \mathrm{~b}$ \\
\hline Komeett & $2.6 \mathrm{a}$ & $2.7 \mathrm{a}$ & $4.9 \mathrm{ab}$ & $3.7 \mathrm{c}$ & $43.3 \mathrm{~b}$ & $0.14 \mathrm{ab}$ \\
\hline Liberty & $2.5 \mathrm{ab}$ & $2.4 \mathrm{~b}$ & $4.9 \mathrm{ab}$ & $3.9 \mathrm{bc}$ & $48.4 \mathrm{~b}$ & $0.13 \mathrm{ab}$ \\
\hline Sheva Sheva & $2.3 \mathrm{~b}$ & $2.4 \mathrm{~b}$ & $4.8 \mathrm{ab}$ & $3.9 \mathrm{bc}$ & $45.2 \mathrm{~b}$ & $0.13 \mathrm{ab}$ \\
\hline Success & $2.6 \mathrm{a}$ & $2.2 \mathrm{bc}$ & $4.3 \mathrm{~b}$ & $3.7 \mathrm{c}$ & $49.5 \mathrm{~b}$ & $0.14 \mathrm{ab}$ \\
\hline
\end{tabular}

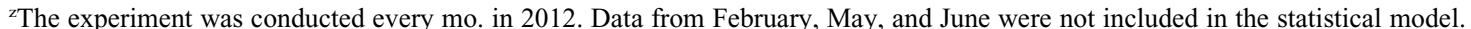

y Data represent a pooled average for seedlings grown under natural solar light only (control); natural + supplemental light (SL) from a high-pressure sodium lamp, and natural + SL from light-emitting diodes using different red and blue percentages.

${ }^{x}$ Means within columns followed by the same letter are not different based Tukey's honestly significant difference test at $P \leq 0.05$.

\section{Conclusion}

For all tomato cultivars evaluated, a combination of red and blue wavebands in SL has potential to increase seedling growth compared with blue-deficient SL treatments in overcast, variable-DLI climates. As indicated by studies evaluating effects of narrow-spectrum lighting on plant growth and development as well as testing of LED technologies for greenhouse operations, LEDs are a promising SL technology for propagating greenhouse crops. Nonetheless, significant opportunities remain to optimize spectral-quality effects on plant growth and development. Considerable genetic variability across species (and sometimes cultivars) exists for plant responses to different red:blue photon flux ratios as well as to other wavelengths that may alter seedling morphology. In addition, studies of targeted lighting, changing spectral composition throughout crop life cycles, and photomorphogenic optimization of leaf-light interactions are areas for further inquiry to fully leverage the benefits of LEDs as SL sources.

\section{Literature Cited}

Arthur, J.M. 1936. Plant growth in continuous illumination. In: Duggar, B.M. (ed.). Biological effects of radiation, 2. McGraw-Hill Book Company, New York, NY.

Ballaré, C.L., P.W. Barnes, and S.D. Flint. 1995 Inhibition of hypocotyl elongation by ultraviolet$\mathrm{B}$ radiation in de-etiolating tomato seedlings, I. The photoreceptor. Physiol. Plant. 93:584-592.

Bleasdale, J.K.A. 1973. Plant physiology in relation to horticulture. Macmillan Press, London, UK.

Blom, T.J., M.J. Tsujita, and G.L. Roberts. 1995. Far-red at end of day and reduced irradiance affect plant height of Easter and Asiatic hybrid lilies. HortScience 30:1009-1012.

Brown, C.S., A.C. Schuerger, and J.C. Sager. 1995. Growth and photomorphogenesis of pepper plants under red light-emitting diodes with supplemental blue or far-red lighting. J. Amer. Soc. Hort. Sci. 120:808-813.

Bruggink, G.T. 1987. Influence of light on the growth of young tomato, cucumber, and sweet pepper plants in the greenhouse: Calculating the effect of differences in light integral. Sci. Hort. 31:175-183.

Calvert, A. 1959. Effect of the early environment on the development of flowering in tomato: II. Light and temperature interactions. J. Hort. Sci. $34: 154-162$.

Cao, W. and T.W. Tibbitts. 1992. Temperature cycling periods affect growth and tuberization in potatoes under continuous light. HortScience 27:344-345.
Chia, P.-L. and C. Kubota. 2010. End-of-day farred light quality and dose requirements for tomato rootstock hypocotyl elongation. HortScience 45:1501-1506.

Cope, K.R. and B. Bugbee. 2013. Spectral effects of three types of white light-emitting diodes on plant growth and development: Absolute versus relative amounts of blue light. HortScience 48:504-509.

Cosgrove, D.J. and P.B. Green. 1981. Rapid suppression of growth by blue light. Plant Physiol. 68:1447-1453.

Craver, J.K., C.T. Miller, K.A. Williams, and D.L. Boyle. 2014. Characterization and comparison of lesions on ornamental sweetpotato 'Blackie', tomato 'Maxifort', interspecific geranium 'Caliente Coral', and bat-faced cuphea 'Tiny Mice'. J. Amer. Soc. Hort. Sci. 139:603-615.

Cushman, K.E. and T.W. Tibbitts. 1998. The role of ethylene in the development of constantlight injury of potato and tomato. J. Amer. Soc. Hort. Sci. 123:239-245.

Decoteau, D.R. and H.H. Friend. 1991. Growth and subsequent yield of tomatoes following end-ofday light treatment of transplants. HortScience 26:1528-1530.

Demers, D.A., M. Dorais, H.C. Wien, and A. Gosselin. 1998. Effects of supplemental light duration on greenhouse tomato (Lycopersicon esculentum Mill.) plants and fruit yields. Sci. Hort. 74: 295-306.

Demers, D.A. and A. Gosselin. 2002. Growing greenhouse tomato and sweet pepper under supplemental lighting: Optimal photoperiod, negative effects of long photoperiod and their causes. Acta Hort. 580:83-88.

Dorais, M., S. Yelle, and A. Gosselin. 1996. Influence of extended photoperiod on photosynthate partitioning and export in tomato and pepper plants. N. Z. J. Crop Hort. Sci. 24:2937.

Dougher, T.A.O. and B. Bugbee. 2001. Differences in the response of wheat, soybean, and lettuce to reduced blue radiation. Photochem. Photobiol. 73:199-207.

Fan, X.-X., Z.-G. Xu, X.-Y. Liu, C.-M. Tang, L.-W. Wang, and X.-I. Han. 2013. Effects of light intensity on the growth and leaf development of young tomato plants grown under a combination of red and blue light. Sci. Hort. 153:50-55.

Gislerød, H.R., L.M. Mortensen, S. Torre, H. Pettersen, T. Dueck, and A. Samd. 2012. Light energy savings in modern greenhouse production. Acta Hort. 956:85-98.

Globig, S., I. Rosen, and H.W. Janes. 1997. Continuous light effects on photosynthesis and carbon metabolism in tomato. Acta Hort. 418:141-152

Goins, G.D., N.C. Yorio, M.M. Sanwo-Lewandowski, and C.S. Brown. 1998. Life cycle experiments with Arabidopsis under red light-emitting diodes (LEDs). Life Support Biosph. Sci. 5:143-149.

Gunnlaugsson, B. and S. Adalsteinsson. 2006. Interlight and plant density in year-round production of tomato at northern latitudes. Acta Hort. 711:71-75.

Heo, J.W., D.H. Kang, H.S. Bang, S.G. Hong, C. Chun, and K.K. Kang. 2012. Early growth, pigmentation, protein content, and phenylalanine ammonia-lyase activity of red curled lettuces grown under different lighting conditions. Kor. J. Hort. Sci. Technol. 30:6-12.

Hernández, R. and C. Kubota. 2012. Tomato seedling growth and morphological responses to supplemental LED lighting red:blue ratios under varied daily solar light integrals. Acta Hort. 956:187-194.

Hernández, R. and C. Kubota. 2014a. LEDs supplemental lighting for vegetable transplant production: Spectral evaluation and comparisons with HID technology. Acta Hort. 1037:829836.

Hernández, R. and C. Kubota. 2014b. Growth and morphological response of cucumber seedlings to supplemental red and blue photon flux ratios under varied solar daily light integrals. Sci. Hort. 173:92-99.

Hillman, W.S. 1956. Injury of tomato plants by continuous light and unfavorable photoperiodic cycles. Amer. J. Bot. 43:89-96.

Hirai, T., W. Amaki, and H. Watanabe. 2006. Action of blue or red monochromatic light on stem internodal growth depends on plant species. Acta Hort. 711:345-350.

Hoenecke, M.E., R.J. Bula, and T.W. Tibbitts. 1992. Importance of 'blue' photon levels for lettuce seedlings grown under red-light-emitting diodes. HortScience 27:427-430.

Hogewoning, S.W., D. Peter, G. Trouwborst, W. van Ieperen, and J. Harbinson. 2010a. An artificial solar spectrum substantially alters plant development compared with usual climate room irradiance spectra. J. Expt. Bot. 61:1267-1276.

Hogewoning, S.W., G. Trouwborst, H. Maljaars, H. Poorter, W. van Ieperen, and J. Harbinson. 2010b. Blue light dose-responses of leaf photosynthesis, morphology, and chemical composition of Cucumis sativus grown under different combinations of red and blue light. J. Expt. Bot. 61:3107-3117.

Hogewoning, S.W., G. Trouwborst, E. Meinen, and W. van Ieperen. 2012. Finding the optimal growth-light spectrum for greenhouse crops. Acta Hort. 956:357-363.

Hurd, R. and J.H.M. Thornley. 1974. An analysis of the growth of young tomato plants in water culture at different light integrals and $\mathrm{CO}_{2}$ concentrations. I. Physiological aspects. Ann. Bot. (Lond.) 38:375-388.

Johkan, M., K. Shoji, F. Goto, S. Hashida, and T. Yoshihara. 2010. Blue light-emitting diode light irradiation of seedlings improves seedling 
quality and growth after transplanting in red leaf lettuce. HortScience 45:1809-1814.

Jones, J.B., Jr. 2008. Tomato plant culture: In the field, greenhouse, and home garden. 2nd Ed. CRC Press, Boca Raton, FL.

Kasperbauer, M.J. and D.E. Peaslee. 1973. Morphology and photosynthetic efficiency of tobacco leaves that received end-of-day red or far red light during development. Plant Physiol. 52:440-442.

Kigel, J. and D.J. Cosgrove. 1991. Photoinhibition of stem elongation by blue and red light: Effects and cell wall properties. Plant Physiol. 95:1049-1056.

Kim, H.-H., R.M. Wheeler, J.C. Sager, N.C. Yorio, and G.D. Goins. 2005. Light-emitting diodes as an illumination source for plants: A review of research at Kennedy Space Center. Habitation (Elmsford) 10:71-78.

Lee, J.M., C. Kubota, S.J. Tsao, Z. Bie, P. Hoyos Echevarria, L. Morra, and M. Oda. 2010. Current status of vegetable grafting: Diffusion, grafting techniques, automation. Sci. Hort. 127:93-105.

Li, Q. and C. Kubota. 2009. Effects of supplemental light quality on growth and phytochemicals of baby leaf lettuce. Environ. Expt. Bot. 67:5964.

Liu, X.Y., S.R. Guo, Z.G. Xu, X.L. Jiao, and T. Tezuka. 2011. Regulation of chloroplast ultrastructure, cross-section anatomy of leaves, and morphology of stomata of cherry tomato by different light irradiations of light emitting diodes. HortScience 46:217-221.

Lund, J.B., T.J. Blom, and J.M. Aalyng. 2007. Endof-day lighting with different red/far-red ratios using light-emitting diodes affects plant growth of Chrysanthemum $\times$ morifolium Ramat. 'Coral Charm'. HortScience 42:1609-1611.

Massa, G.D., H.-H. Kim, R.M. Wheeler, and C.A. Mitchell. 2008. Plant productivity in response to LED lighting. HortScience 43: 1951-1956.

Matsuda, R., N. Ozawa, and K. Fujiwara. 2012. Effects of continuous lighting with or without a diurnal temperature difference on photosynthetic characteristics of tomato leaves. Acta Hort. 956:165-170.

Matsuda, R., N. Ozawa, and K. Fujiwara. 2014. Leaf photosynthesis, plant growth, and carbohydrate accumulation of tomato under different photoperiods and diurnal temperature differences. Sci. Hort. 170:150-158.

McAvoy, R.J. and H.W. Janes. 1990. Cumulative light effects on growth and flowering of tomato seedlings. J. Amer. Soc. Hort. Sci. 115:119122.

McCree, K.J. 1972. The action spectrum absorptance and quantum yield of photosynthesis in crop plants. Agr. Meteorol. 9:191-216.

Moe, R. 1997. Physiological aspects of supplementary lighting in horticulture. Acta Hort. 418:17-24.

Moe, R., S.O. Grimstad, and H.R. Gislerød. 2006. The use of artificial light in year round production of greenhouse crops in Norway. Acta Hort. 711:35-42.

Murage, E.N. and M. Masuda. 1997. Response of pepper and eggplant to continuous light in relation to leaf chlorosis and activities of antioxidative enzymes. Sci. Hort. 70:269-279.

Nanya, K., Y. Ishigami, S. Hikosaka, and E. Goto. 2012. Effects of blue and red light on stem elongation and flowering of tomato seedlings. Acta Hort. 956:264-266.

Ohyama, K., Y. Omura, and T. Kozai. 2005a. Effects of air temperature regimes on physiological disorders and floral development of tomato seedlings grown under continuous light. HortScience 40:1304-1306.

Ohyama, K., K. Manabe, Y. Omura, T. Kozai, and C. Kubota. 2005b. Potential use of a 24-hour photoperiod (continuous light) with alternating air temperature for production of tomato plug transplants in a closed system. HortScience 40:374-377.

Omura, Y., Y. Oshima, C. Kubota, and T. Kozai. 2001. Treatments of fluctuating temperature under continuous light enabled the production of quality transplants of tomato, eggplant and sweet pepper. HortScience 36:508.

Savvides, A., D. Fanourakis, and W. van Ieperen. 2012. Co-ordination of hydraulic and stomatal conductances across light qualities in cucumber leaves. J. Expt. Bot. 63:1135-1143.

Shinkle, J.R. and R.L. Jones. 1988. Inhibition of stem elongation in Cucumis seedlings by blue light requires calcium. Plant Physiol. 86:960-966.

Sysoeva, M.I., T.G. Shibaeva, E.G. Sherudilo, and E.N. Ikkonen. 2012. Control of continuous irradiation injury on tomato plants with a temperature drop. Acta Hort. 956:283-289.
Tibbitts, T.W., S.M. Bennett, and W. Cao. 1990. Control of continuous irradiation injury on potato with daily temperature cycling. Plant Physiol. 93:409-411.

Tripathy, B.C. and C.S. Brown. 1995. Root-shoot interaction in the greening of wheat seedlings grown under red light. Plant Physiol. 107:407411.

Trouwborst, G., J. Oosterkamp, S.W. Hogewoning, J. Harbinson, and W. van Ieperen. 2010. The responses of light interception, photosynthesis and fruit yield of cucumber to LED-lighting within the canopy. Physiol. Plant. 138:289300.

van Ieperen, W., A. Savvides, and D. Fanourakis. 2012. Red and blue light effects during growth on hydraulic and stomatal conductance in leaves of young cucumber plants. Acta Hort. 956:223-230.

Volmaro, C., M. Pontín, V. Luna, R. Baraldi, and R. Bottini. 1998. Blue light control of hypocotyl elongation in etiolated seedlings of Lactuca sativa (L.) cv. Grand Rapids related to exogenous growth regulators and endogenous IAA, $\mathrm{GA}_{3}$ and abscisic acid. Plant Growth Regulat. 26:165-173.

Wang, H., M. Gu, J. Cui, K. Shi, T. Zhou, and J. Yu. 2009. Effects of light quality on $\mathrm{CO}_{2}$ assimilation, chlorophyll-fluorescence quenching, expression of Calvin cycle genes and carbohydrate accumulation in Cucumis sativus. J. Photochem. Photobiol. 96:30-37.

Withrow, A.P. and R.B. Withrow. 1949. Photoperiodic chlorosis in tomato. Plant Physiol. 24: 657-663.

Wu, M.C., C.Y. Hou, C.M. Jiang, Y.T. Wang, C.Y Wang, H.H. Chen, and H.M. Chang. 2007. A novel approach of LED light radiation improves the antioxidant activity of pea seedlings. Food Chem. 101:1753-1758.

Yorio, N.C., G.D. Goins, H.R. Kagie, R.M Wheeler, and J.C. Sager. 2001. Improving spinach, radish and lettuce growth under red light emitting diodes (LEDs) with blue light supplementation. HortScience 36:380-383.

Yorio, N.C., R.M. Wheeler, G.D. Goins, M.M. Sanwo-Lewandowski, C.L. Mackowiak, C.S. Brown, J.C. Sager, and G.W. Stutte. 1998. Blue light requirements for crop plants used in bioregenerative life support systems. Life Support Biosph. Sci. 5:119-128. 